\title{
https://doi.org/10.46344/JBINO.2020.v09i04.10
}

\section{EVALUATION OF THE PROXIMATE COMPOSITION OF FIVE COMMON BUT UNDERUTILIZED MEDICINAL PLANTS IN NIGERIA}

*Arogbodo, J. $\mathrm{O}^{1}$ and Ajayi, O. A²

\begin{abstract}
'Department of Animal Production and Health, School of Agriculture and Agricultural Technology, P.M.B. 704, Federal University of Technology, Akure
\end{abstract}

2Department of Chemistry, School of Sciences, Federal University of Technology, Akure

(Received on Date: $21^{\text {st }}$ April 2020

Date of Acceptance: 18 ${ }^{\text {th }}$ May 2020 Date of Publish: 01 ${ }^{\text {st }}$ July 2020 )

Email id: arogbodojos@yahoo.com

\begin{abstract}
In order to ascertain the nutritional composition of five medicinal plants viz; Lantana camara (LC), Nicotiana tabacum (NT), Harungana madagascariensis (HM), Parquetina nigrescens (PN) and Alchornea cordifolia (AC), their proximate analyses were carried out following standard methods of AOAC and data analysed using SPSS Version 23. The results showed significant differences $(P<0.05)$ with $N T$ having highest ash, fat, fibre and metabolizable energy (ME) values. The crude protein results followed the order of $H M>P N$ $>\mathrm{NT}>\mathrm{LC}>\mathrm{AC}$; moisture content, $\mathrm{PN}>\mathrm{HM}>\mathrm{LC}>\mathrm{LT}>\mathrm{AC}$; ash, $\mathrm{NT}>\mathrm{PN}>\mathrm{LC}>\mathrm{AC}>\mathrm{HM}$; fat, $\mathrm{NT}>\mathrm{PN}>\mathrm{LC}>\mathrm{HM}>\mathrm{AC}$; fibre, $\mathrm{NT}>\mathrm{PN}>\mathrm{LC}>\mathrm{HM}>\mathrm{AC}$; carbohydrate, $\mathrm{AC}>\mathrm{LC}>\mathrm{HM}>$ $\mathrm{PN}>\mathrm{NT}$, and metabolizable energy, NT $>\mathrm{PN}>\mathrm{LC}>\mathrm{HM}>\mathrm{AC}$. The appreciable ME content $\left(3001.91 \pm 45.16^{c}\right.$ to $\left.3321.35 \pm 9.4^{\mathrm{a}} \mathrm{Kcal} / \mathrm{Kg}\right)$ and other nutrients assessed in the five plants serve as pointers to the fact that they could be reckoned with as cheap and veritable source of energy (and concurrently other nutrients) analysed for poultry diets formulation.
\end{abstract}

Key words: Medicinal plants, leaf meal, proximate composition, poultry 


\section{INTRODUCTION}

Researchers have grown a significantly interest in the usage of leaf meal, most importantly in poultry production in recent years. The interest has been due to the nutritional and medicinal properties among others, derivable from medicinal plants. They are rich source of bioactive constituents that are indispensable to the normal well-being of poultry (Rama et al., 2019). Bioactive compounds like phytochemicals and phytobiotics possess growth promoting, therapeutic efficacy (Murugesan, 2005) immunomodulatory effect (Lillehoj et al., 2011) free radical scavenging potential (Sumaira et al., 2015), as well as antimicrobial property (Jamroz, et al., 2005). In agreement with the innumerable benefits obtainable from leaf meals, it was hitherto recommended in poultry diets (Oloruntola, et al., 2016). Incorporation of leaf meal in poultry diets was demonstrated with appreciable results using Gliricidia sepium leaf (KagyaAgyemang et al., 2007), Carica papaya leaf (Onyimonyi and Ernest, 2009), Cymbopogon citratus leaf (Mmereole, 2010), Psidium guajava leaf (Pandey and Shweta, 2011), Moringa oleifera leaf (Liaqat et al., 2016; Manjaniq et al., 2017), Polyalthia longifolia leaf (Alagbe, 2017), Eucalyptus globulus leaf (Farhadi et al., 2017; Mashayekhi et al., 2018), and Sauropus androgynus leaf (Prakoso, 2018). Despite the numerous literature reviews on the above medicinal plants, less has been reported on Lantana camara Linn, Nicotiana tabacum Linn, Harungana

madagascariensis,

Parquetina nigrescens and Alchornea cordifolia. L. camara Linn otherwise known as wild sage, Lantana, sleeper weed etc belongs to the family Verbenaceae (genus Lantana) has been described to be noxious and invasive (Dobhal et al., 2011). This plant has been reported to be a very essential medicinal plants to be reckoned with in the world (Ross, 1999). It is a flowering plant usually found in the tropical and sub-tropical South America, West Indies, Asia-Pacific region, Australia, New Zealand and Africa, with a characteristic aromatic smell. It is usually called "Ewon Agogo" or "Ewon adele" in Yoruba land, "Anya nnunu" in Igbo and "Kimbamahalba" in Hausa (Ajiboye et al., 2014; Egharevba et al., 2015). The plant contains toxic substances called lantadene A - D, lantanolic and lantic acid having antimicrobial property. Reports from several researchers displayed the plant as antifungal, antitumour, antimalarial, wound healing and analgesic medicinal plant (Deena and Thoppil, 2000; Verma and Verma, 2006). L. camara has hepatoprotective effects and other activities ranging from antioxidant, larvicidal, antidiabetic, antimotility, antiinflammatory, antiurolithiatic, antifertility, and cytotoxic (Sanjeeb, 2012). N. tabacum Linn (Solanaceae) was said to have originated from South America and now cultivated in so many parts of the world like India, China, Cambodia Malaysia, etc as a cash crop (Charlton 2004, Binorkar and Jani 2012). The plant has lots of pharmacological potentials and usage in many countries like Brazil, China, Colombia, Cuba, Egypt, Eucador and many others. In Nigeria, hot water infusion of the leaf of the plant is used as sedative while the processed sun-dried 
and well ground leaves is used as stimulant and in the treatment of convulsions (Adesina 1982; Bhat et al., 1985). H. madagascariensis (Lam. Ex Poir), a native to Madagascar is a member of the family Hypericaceae formerly known as Gutifferae. The medicinal importance of the plant made it to be imported to Africa. The leaves, stem-bark, including its roots have been documented to possess antibacterial, antifungal, and antiviral activities (IWU, 1994). P. nigrescens (Perplocaceae) is a very useful medicinal plant traditionally in the treatment of gastro-intestinal complications, sickle cell anaemia and other health challenges (Imaga et al., 2010; Ayoola et al., 2011). The plant is very common around villages and farms in Nigeria. A. cordifolia (Euphorbiaceae) is a perennial shrub that is very common in West Africa, especially in Nigeria (Oliver, 1986). The extract of the plant possesses antibacterial property already experimented in vitro and in vivo (Merlin et al., 2017) and as such could be a promising candidate for leaf meal preparation in broiler diets (Oloruntola, et al., 2016). L. camara Linn, N. tabacum, $H$. madagascariensis, $P$. nigrescens and $A$. cordifolia are common and available medicinal plants whose potentials have not been well exploited as leaf meal for poultry diets in Nigeria. Information on them regards this purpose are very scanty, hence the importance and pertinence of this study.

\section{Materials and methods}

\section{Collection and preparation of the medicinal plants}

Fresh leaves of each of the plants in their natural habitat were plucked in Akure, Ondo State (Latitude: 7.26785, Longitude:
5.14746 N 7016'3.96'', E 508'51.028'') in the month of August, 2019. Akure is on 9 $M$ above sea level with mean annual rainfall and temperature of $2378 \mathrm{~mm}$ and of $26.7 \circ \mathrm{C}$ respectively. After proper identification, the leaves were individually packed in baskets and rinsed in turn under running tap water in order to get rid of any possible dust particles from them. They were thereafter arranged in flat trays and air-dried under shade. The samples became brittle after twelve (12) days of air-drying. Pulverization to fine particles was carried out using Bajaj Twister Mixer Electric Grinder (3 Jar QC. NO: HP/14/001/0064). All the samples were stored in air-tight plastic containers at $4 \circ \mathrm{C}$ until the commencement of Laboratory analyses.

\section{Proximate analysis}

The proximate analyses were determined following standard methods (AOAC, 2006). Moisture content; by the drying/indirect method and total ash by weighing $2 \mathrm{~g}$ each of the leaf samples into the crucible. The samples were ashed in a muffle furnace at a temperature of $550^{\circ} \mathrm{C}$, cooled in a desiccator and weighed. The total ash was then calculated. Crude fat was obtained using Soxhlet direct (petroleum ether) solvent extraction method (Reinik et al., 2007). This process involved weighing $3 \mathrm{~g}$ each of the leaf samples into a thimble and plugged into the soxhlet extractor with cotton wool. The solvent was poured into a round bottom flask which later fitted to the soxhlet and placed on a heating mantle. The oil was extracted as the solvent was refluxed several times. The extraction lasted for about 7 hours after which the flask was 
cooled and disconnected. The final weight was recorded and the fat content was calculated. Crude fibre was determined according to the method of Pearson, (1976). Crude protein was determined using Macro kjeldahl method from the nitrogen content by the protein conversion factor 6.25 to give the crude protein content (Pearson, 1976). The percentage carbohydrate was obtained by difference that is $100-$ (\% Protein $+\%$ Ash $+\%$ Crude fibre $+\%$ Moisture $+\%$ Fat) while the ME (Kcal/Kg) was obtained by calculation (Janssen, 1989).

\section{Statistical analysis}

All data were analysed using SPSS Computer Software Package Version 23 (SPSS, 2015).

\section{Results and discussion}

The results obtained from this experiment for the five selected medicinal plants are as shown in Table 1 with their pictorial representations (Figures 1 to 5).

\section{Table 1: Proximate nutrient composition of five selected medicinal plants in Nigeria}

\begin{tabular}{|c|c|c|c|c|c|c|}
\hline \multirow[t]{2}{*}{ Parameters (\%) } & \multicolumn{5}{|c|}{ Medicinal plant samples } & \multirow[b]{2}{*}{$\begin{array}{l}\text { Sig } \\
\text { level }\end{array}$} \\
\hline & $\mathrm{LC}$ & NT & $\mathrm{HM}$ & PN & $\mathrm{AC}$ & \\
\hline Moisture & $\begin{array}{ll}13.48 & \pm \\
0.20^{\mathrm{b}} & \end{array}$ & $\begin{array}{ll}12.99 & \pm \\
0.23^{\mathrm{b}} & \end{array}$ & $\begin{array}{ll}14.29 & \pm \\
0.17^{\mathrm{a}} & \end{array}$ & $\begin{array}{ll}14.31 & \pm \\
0.21^{\mathrm{a}} & \end{array}$ & $\begin{array}{ll}11.39 & \pm \\
0.39^{\mathrm{c}} & \end{array}$ & $* * *$ \\
\hline Total ash & $\begin{array}{ll}11.69 & \pm \\
0.41^{b} & \end{array}$ & $\begin{array}{l}19.88 \\
0.37^{\mathrm{a}}\end{array}$ & $\begin{array}{l}5.58 \\
0.33^{\mathrm{c}}\end{array}$ & $\begin{array}{l}12.22 \\
0.57^{\mathrm{b}}\end{array}$ & $\begin{array}{ll}5.84 & \pm \\
0.40^{\mathrm{c}} & \end{array}$ & $* * *$ \\
\hline Crude fat & $\begin{array}{|ll|}9.29 & \pm \\
0.18^{\mathrm{c}} & \\
\end{array}$ & $\begin{array}{l}12.51 \\
0.17^{\mathrm{a}}\end{array}$ & $\begin{array}{l}9.27 \\
0.19^{c}\end{array}$ & $\begin{array}{l}11.12 \\
0.14^{\mathrm{b}}\end{array}$ & $\begin{array}{l}6.32 \\
0.51^{\mathrm{d}}\end{array}$ & $* * *$ \\
\hline Crude protein & $\begin{array}{ll}8.79 & \pm \\
0.34^{\mathrm{cd}} & \end{array}$ & $\begin{array}{l}9.50 \\
0.17^{c}\end{array}$ & $\begin{array}{l}15.68 \\
0.39^{\mathrm{a}}\end{array}$ & $\begin{array}{ll}14.02 & \pm \\
0.14^{\mathrm{b}} & \end{array}$ & $\begin{array}{l}8.52 \\
0.29^{d}\end{array}$ & $* * *$ \\
\hline Crude fibre & $\begin{array}{ll}1.14 & \pm \\
0.10^{\mathrm{c}} & \end{array}$ & $\begin{array}{ll}9.50 & \pm \\
0.09^{\mathrm{a}} & \end{array}$ & $\begin{array}{l}0.76 \\
0.06^{\mathrm{c}}\end{array}$ & $\begin{array}{l}2.06 \\
0.05^{\mathrm{b}}\end{array}$ & $\begin{array}{ll}0.23 & \pm \\
0.05^{\mathrm{d}} & \end{array}$ & \\
\hline Carbohydrate & $\begin{array}{ll}55.60 & \pm \\
0.42^{\mathrm{b}} & \end{array}$ & $\begin{array}{ll}44.72 & \pm \\
0.52^{\mathrm{e}} & \end{array}$ & $\begin{array}{ll}54.42 & \pm \\
0.02^{\mathrm{c}} & \end{array}$ & $\begin{array}{l}46.26 \\
0.30^{\mathrm{d}}\end{array}$ & $\begin{array}{l}67.71 \\
0.62^{\mathrm{a}}\end{array}$ & $* * *$ \\
\hline Dry matter & $\begin{array}{ll}86.52 & \pm \\
0.20^{\mathrm{b}} & \end{array}$ & $\begin{array}{ll}87.02 & \pm \\
0.23^{\mathrm{b}} & \\
\end{array}$ & \begin{tabular}{ll|}
85.71 & \pm \\
$0.17^{\mathrm{c}}$ & \\
\end{tabular} & $\begin{array}{ll}85.69 & \pm \\
0.21^{\mathrm{c}} & \end{array}$ & $\begin{array}{ll}88.61 & \pm \\
0.39^{\mathrm{a}} & \end{array}$ & $* * *$ \\
\hline $\mathrm{ME}(\mathrm{Kcal} / \mathrm{Kg})$ & $\begin{array}{l}3065.20 \\
\pm 1.34^{\mathrm{b}}\end{array}$ & $\begin{array}{l}3321.35 \quad \pm \\
9.4^{\mathrm{a}}\end{array}$ & $\begin{array}{|ll|}3062.17 & \pm \\
20.33^{\mathrm{b}} & \\
\end{array}$ & $\begin{array}{l}3095.35 \quad \pm \\
0.69^{\mathrm{b}}\end{array}$ & $\begin{array}{ll}3001.91 & \pm \\
45.16^{\mathrm{c}} & \end{array}$ & $* * *$ \\
\hline
\end{tabular}

Mean values with different superscript along the same row are significantly different $(\mathrm{p}<0.05)$. Sig $=$ Significant, $* * *=$ Highly significant, LC $=$ Lantana camara, $\mathrm{NT}=\mathrm{Nicotiana}$ tabacum, $\mathrm{HM}=\mathrm{H}$ arungana madagascariensis, $\mathrm{PN}=$ Parquetina nigrescens, $\mathrm{AC}=\mathrm{A}$ lchornea cordifolia and $\mathrm{ME}=$ Metabolizable energy. 


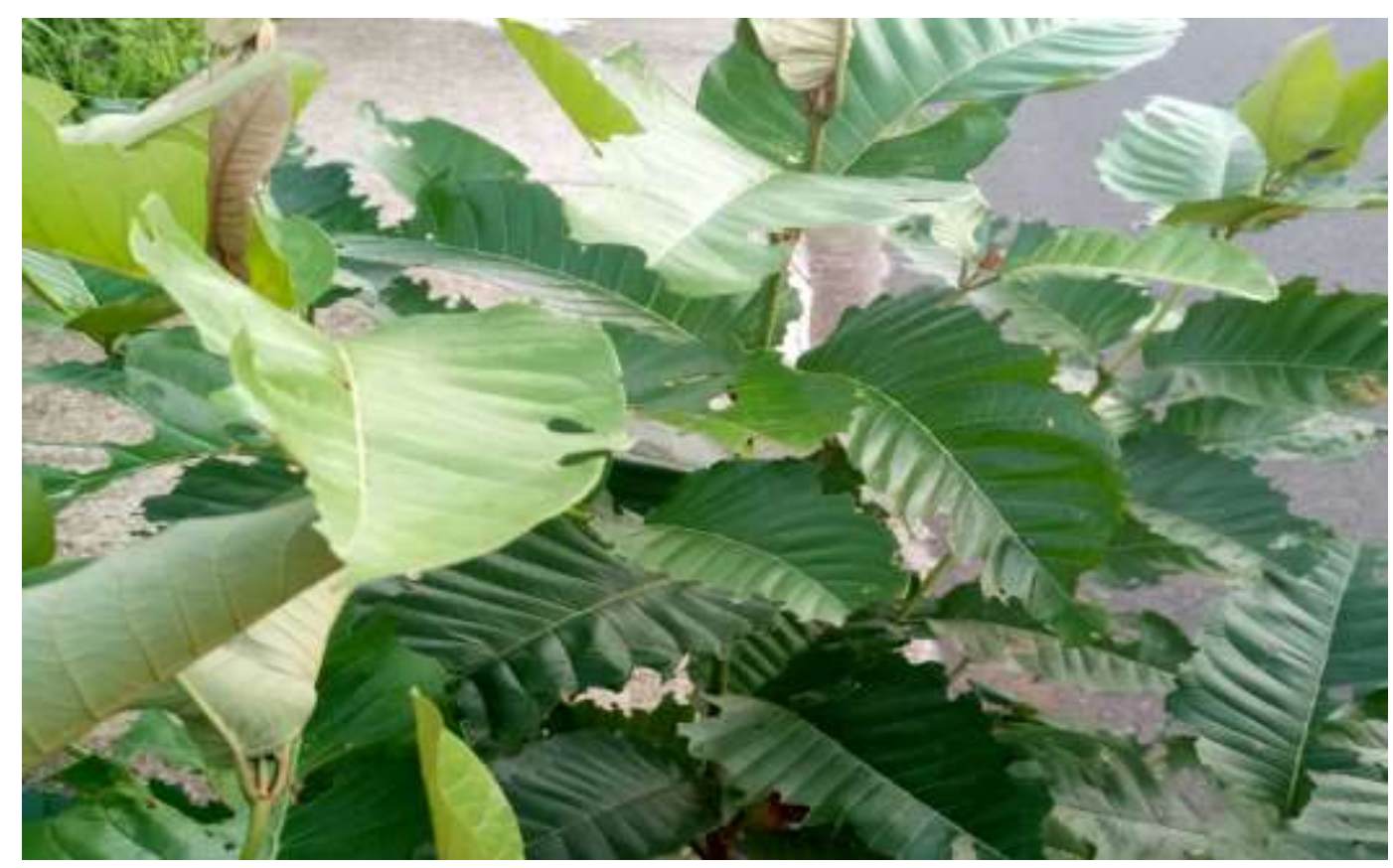

Figure 1: Harungana madagascariensis

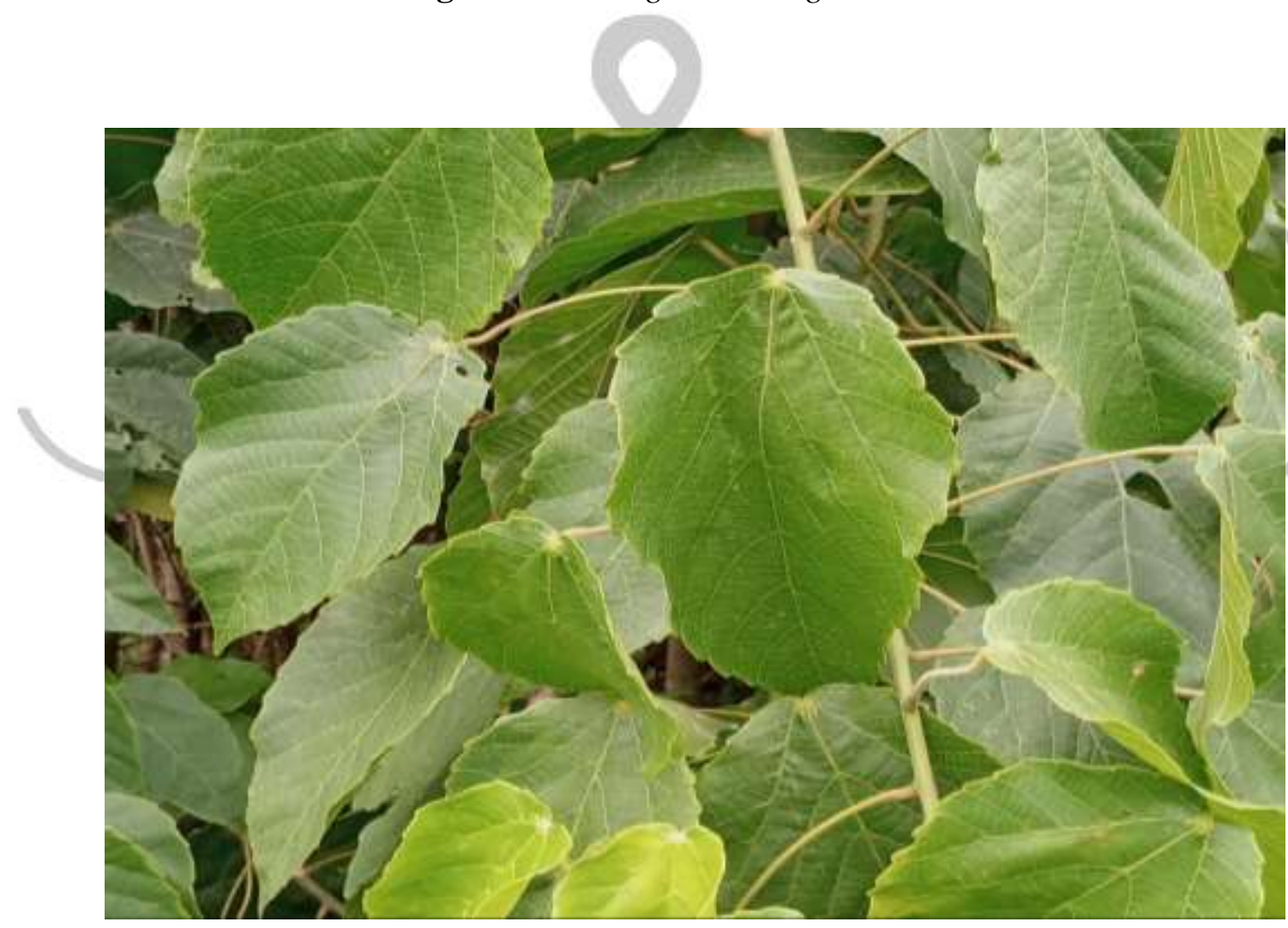

Figure 2: Alchornea cordifolia 


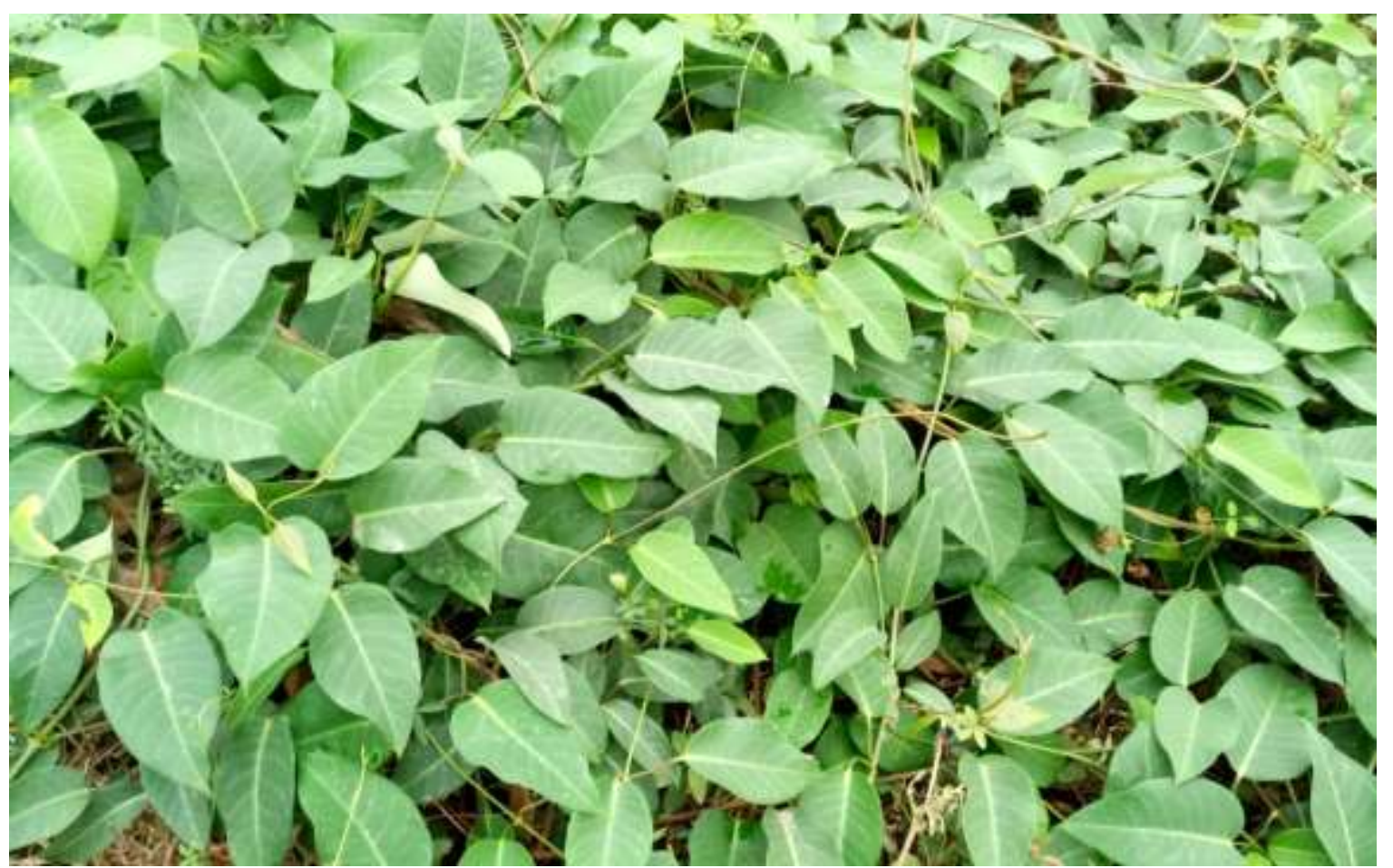

Figure 3: Parquetina nigrescence

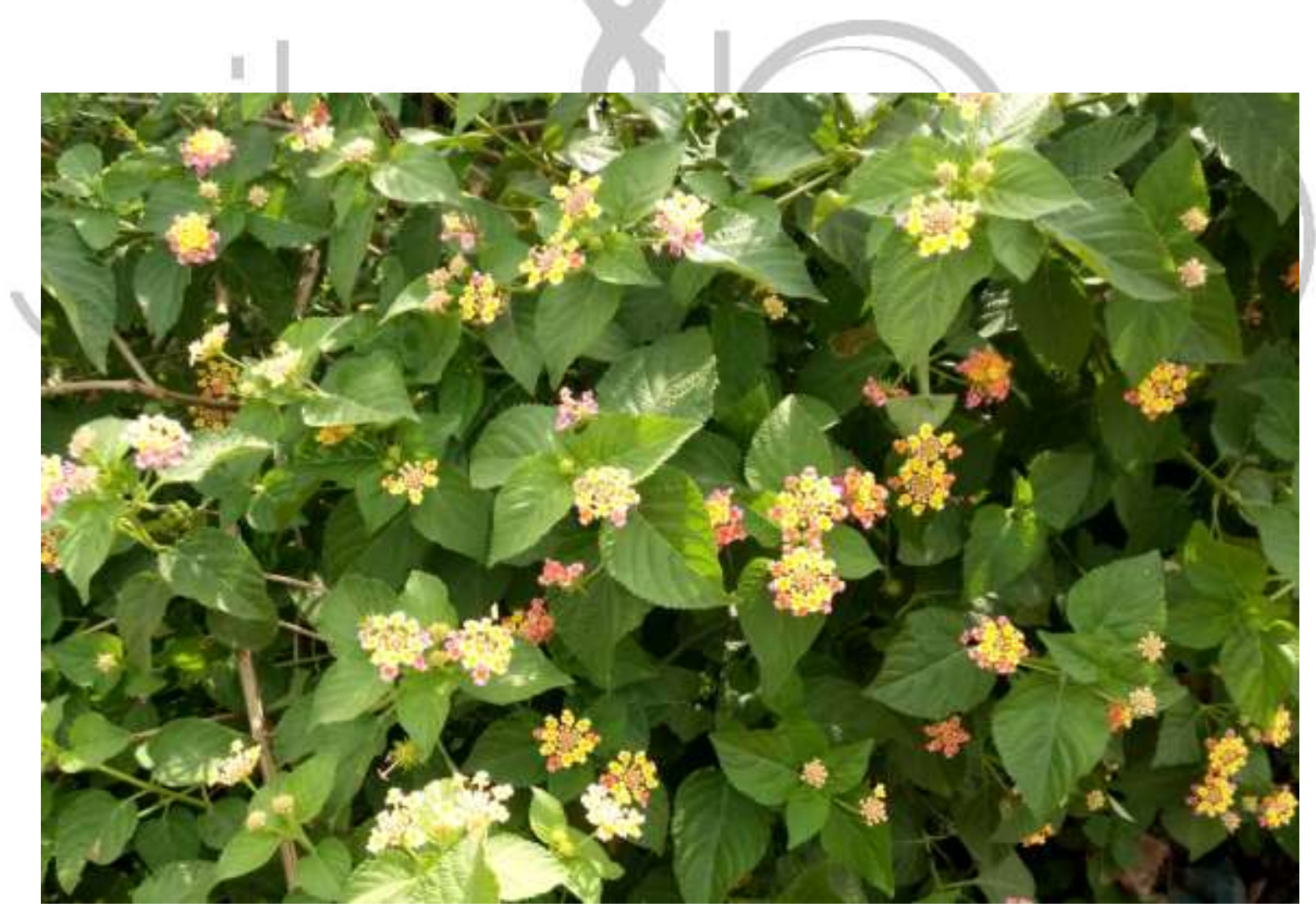

Figure 4: Lantana camara 


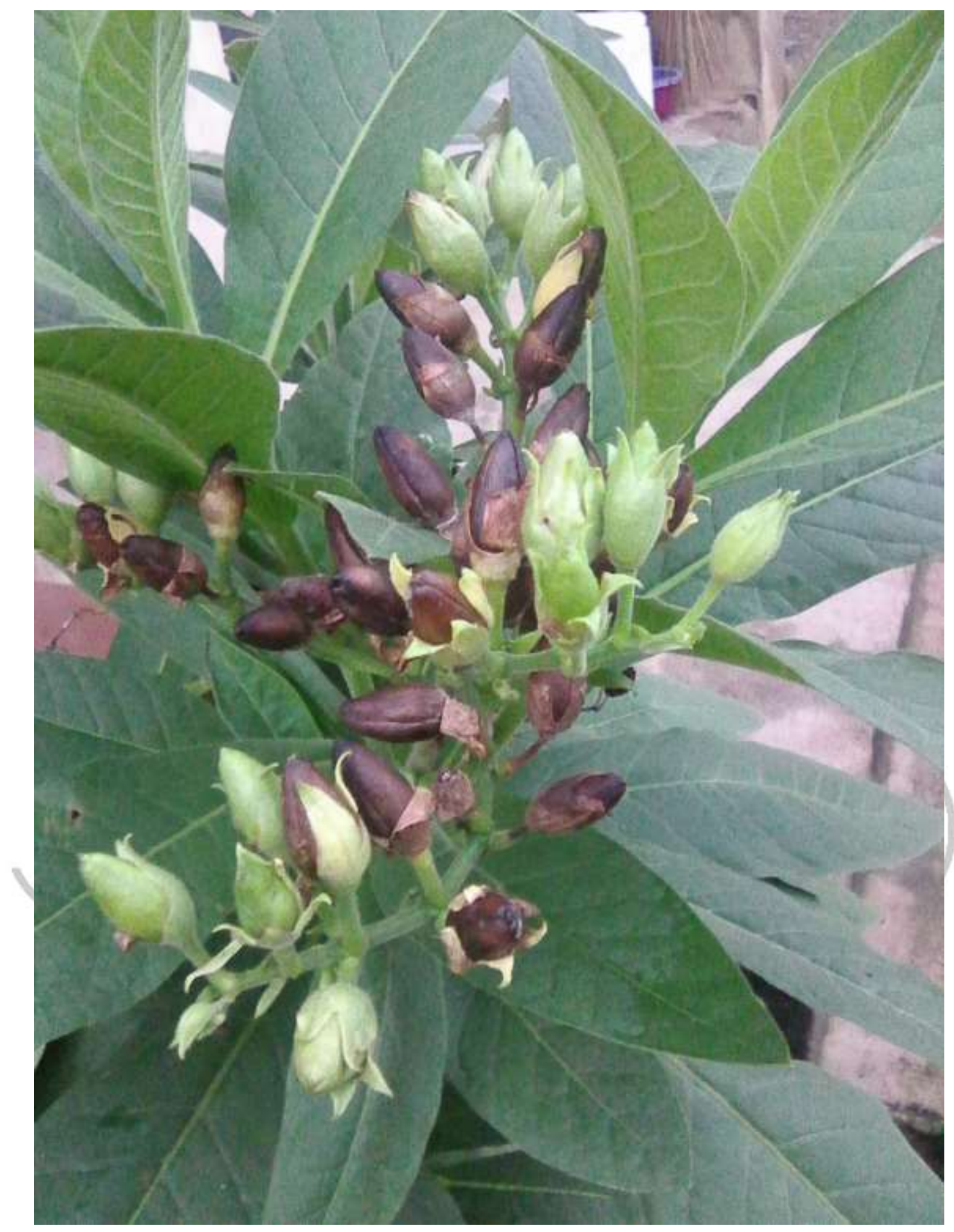

Figure 5: Nicotiana tabacum

2020 July Edition | www.jbino.com | Innovative Association

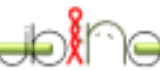


There was an observed highly significant differences $(p<0.05)$ in all the parameters of the proximate analysis among the selected medicinal plants. The moisture content (MC) of the HM and PN had the highest percentage but similar statistical value of $14.29 \pm 0.17 a$ and $14.31 \pm 0.21^{a}$ respectively, followed by LC and NT (13.48 $\pm 0.20^{\mathrm{b}}$ and $12.99 \pm 0.23^{\mathrm{b}}$ ) while the dry matter followed the reverse order. AC had the lowest value of $11.39 \pm 0.39$ c of dry matter content. Total ash was highest in NT (19.88 $\pm 0.37 a)$, followed by PN (12.22 $\pm 0.57 \mathrm{~b})$, LC $\left(11.69 \pm 0.41^{\mathrm{b}}\right)$, AC $(5.84 \pm$ $0.40 \mathrm{c})$ and HM (5.58 $\pm 0.33 \mathrm{c})$ in that order. The ash values of $L C$ and $P N$ were not statistically different, so also the ash values of HM and AC. Crude fat was found to be in decreasing order from NT (12.51 \pm $0.17 a), P N\left(11.12 \pm 0.14\right.$ b) , LC (9.29 $\left.\pm 0.18^{c}\right)$, $\operatorname{HM}(9.27 \pm 0.19 c)$, to $A C(6.32 \pm 0.51 d)$. The crude fat of LC and HM were not statistically different. Crude protein was highest in HM (15.68 \pm 0.39 ), followed by PN $(14.02 \pm 0.14 \mathrm{~b})$, NT $(9.50 \pm 0.17 \mathrm{c})$, LC $(8.79 \pm 0.34 \mathrm{~cd})$, and lowest in $A C(8.52 \pm$ $0.29 \mathrm{~d})$. NT had the highest value $(9.50 \pm$ 0.09 ) for crude fibre, followed by PN (2.06 $\left.\pm 0.05^{b}\right), \operatorname{LC}\left(1.14 \pm 0.10^{c}\right), \mathrm{HM}\left(0.76 \pm 0.06^{\mathrm{c}}\right)$ and finally $A C(0.23 \pm 0.05 \mathrm{~d})$. There was no significant difference between the mean crude fibre values of LC and HM. Carbohydrate highest value was recorded in $A C$ (67.71 \pm 0.62 ) followed by LC $\left(55.60 \pm 0.42^{b}\right), H M\left(54.42 \pm 0.02^{c}\right)$, PN $(46.26 \pm 0.30 \mathrm{~d})$ and NT $(44.72 \pm 0.52 \mathrm{e})$ in that order. Calculated ME $(\mathrm{Kcal} / \mathrm{Kg})$ of the plant samples in decreasing order revealed NT to have the highest value (3321.35 \pm 9.4 a), followed by PN (3095.35 \pm $0.69 \mathrm{~b}), \mathrm{LC}(3065.20 \pm 1.34 \mathrm{~b}), \mathrm{HM}$ (3062.17 \pm $\left.20.33^{b}\right)$ and $A C(3001.91 \pm 45.16 c)$. There was no significant difference in the mean values of $\mathrm{ME}(\mathrm{Kcal} / \mathrm{Kg})$ for LC 13065.20 $\left.\pm 1.34^{\mathrm{b}}\right), \mathrm{HM}\left(3062.17 \pm 20.33^{\mathrm{b}}\right)$ and $\mathrm{PN}$ $(3095.35 \pm 0.69 \mathrm{~b})$. The proximate analysis results from all the medicinal plants studied compared favourably well with earlier researchers. The ash content of $L$. camara (11.69 \%) was lower than that (12.06 \%) earlier reported (Sambo et al., 2015) and higher than that of Clement et al. (2018) which were $10.77 \%$ and $2.3 \%$ respectively. The crude protein (8.79\%) and crude fibre of $L$. camara in this study were lower than the results from the analyses of the above authors. However, the result for Carbohydate (55.62 \%) was similar to the former report of Ajiboye et al. (2014) by a slight higher difference of $0.98 \%$. The moisture content, ash, crude fat, and carbohydrate values in $\mathrm{N}$. tabacum were higher than the earlier report (Oyekunle et al., 2019) while crude protein and crude fibre values were lower than those reported by these same authors. The moisture content, ash and crude protein of $H$. madagascariensis were higher and lower in crude fat and crude fibre than those reported. Ash and moisture content were higher in $P$. nigrescens (Afzel.) than those reported by Gbadamosi et al. (2012) and lower than the values of crude fat, crude protein and crude fibre recorded by this same authors. Alchornea cordifolia's proximate composition showed lower ash (5.84 \%), crude fat $(6.32 \%)$, and crude fibre $(0.23$ $\%)$ content compared to other authors (Philip et al., 2014; Nodu et al., 2014). However, the carbohydrate content of $A$. cordifolia in this study (67.71\%) was higher than the earlier report (43.53\%) by the authors above. The value of crude protein 
in each of these five selected plants in this study was higher than those reported for twenty seven selected Nigerian vegetables (Omale, 2010) but compared favourably well (other nutrients inclusive) with the findings of Osuntokun and Olajubu (2014). Likewise, crude protein, total ash, crude fat, and carbohydrate content of all the studied medicinal plants were higher than those reported by Awodi (2017), for Myrianthus arboreus leaves.

\section{Conclusion}

The five medicinal plants analysed in this study are cheap and veritable source of nutrients with Harungana madagascariensis (HM) and Parquetina nigrescens (PN) taking the lead in crude protein, $15.68 \pm 0.39 \mathrm{a} \%$ and $14.02 \pm 0.14 \mathrm{~b}$ $\%$ respectively. Their relatively low fibre content (except Nicotiana tabacum) is a good nutritional quality for their consideration as leaf meal in poultry diets. The high ME values obtained for the plants $\left(3001.91 \pm 45.16^{c}-3321.35 \pm 9.4^{a}\right.$ $\mathrm{Kcal} / \mathrm{Kg}$ ) coupled with their endowed appreciable nutrients could be explored in the formulation of poultry feed. However, supplementation with appropriate enzymes may be grossly essential where the fibre content is high for proper nutrients' utilization.

\section{Recommendations}

The leaves of these plants can be aseptically processed, and thereafter incorporated in form of leaf meal in the diets of poultry birds. Meanwhile, further research into the amino acid profile, mineral, vitamin, anti-nutritional factors, and toxicity effect (if any) of each of the medicinal plants on animals are of paramount value for their acceptance and usefulness in feed preparation.

\section{References}

Adesina, S.K. 1982. Studies on some plants used as anticonvulsants in Amerindian and Africa traditional medicine; Fitoterapia. 53:147-162.

Ajiboye, A.A., Oyedara, O.O., Agboola, D.A. and Familola, O.T. 2014. Evaluation of antibacterial effects and phytochemical analysis of Lantana camara Linn leaf and berry extracts. European Journal of Medicinal Plants 4(3):332-341.

Alagbe, J.O. 2017. Effect of dietary inclusion of Polyalthia longifolia leaf meal as phytobiotic compared with antibiotics on performance, carcass characteristics and haematology of broiler chicken. Scholarly Journal of Agricultural Science, 7, 68-74.

AOAC 2006. Association of Official Analytical Chemists, Official Methods of Analysis of the AOAC. In: Horwitiz, W. (Ed.). $18^{\text {th }}$ Edition. Association of Official Analytical Chemists, Washington D.C., USA.

\section{Awodi, P.A., Awodi, P.I. and Larayetan,} R.A. 2017. Assessment of proximate, mineral and anti-nutritional compositions of Myrianthus arboreus leaves. International Journal of Bioorganic Chemistry 2(3):125-129. 
Ayoola, A.O., Akinloye, O., Oguntibeju, O.O., Oke, J.M. and Odetola, A.A. 2011. Antioxidant activities of Parquetina nigrescens, African Journal of Biotechnology, 10(24): 4920-4925.

Bhat, R.B., Adeloye, A.A. and Etejere, E.O. 1985. Some medicinal plants of Nigeria. Journal of Economic and taxonomic Botany. 6(1):161-165.

Binorkar, S.V. and Jani, D.K. (2012). Traditional medicinal usage of tobacco a review. Spatula DD 2(2):127-134.

Charlton, A. 2004. Medicinal uses of tobacco in history. J. R. Soc. Med. 97(6):292-296.

Doi:10.1177/014107680409700614.

Clement, Y.E., Anthony, A., Nicholas, T.D. and Akorli, S.E. 2018. Nutritional, phytochemical properties and antibacterial potential of Lantana camara against methicilin resistant Staphylococcus aureus. Journal of Animal and veterinary Advances, 17:9599.

Deena, M.J. and Thoppil, J.E. 2000. Antimicrobial activity of the essential oil of Lantana camara. Fitoterapia 71: 453455.

Dobhal, P.K., Kohli, R.K. and Batish, D.R. 2011. Impact of Lantana camara L. invasion on riparian vegetation of Nayar region in Garhwal Himalaya (Uttarakhand, India). Journal of Ecology and the Natural Environment, 3(1): 11-22.

Egharevba, H.M., Ibrahim, J.A., Ebere, U.D., Ugbabe, G. and Wudil, M.I. 2015.
Phytochemical screening chromatographic profiling and pharmacognostic analysis of leaves of Lantana camara Linn. International Journal of Basic and Applied Sciences 4(4):206-21 1 .

Farhadi, K.A., Sadeghi, G., Sheikhahmadi, A., Habibian, M., Raei, A. and Sobhani, K. 2017. The effects of using eucalyptus (Eucalyptus globules L.) leaf powder and its essential oil on growth performance and immune response of broiler chickens. Iranian Journal of Veterinary Research, Shiraz University, 18(158):60-62.

Gbadamosi, I.T., Moody, J.O and Yekini, A.O. 2012. Nutritional composition of ten ethnobotanicals used for the treatment of anaemia in Southwest Nigeria. European Journal of Medicinal Plants 2(2):140-152.

Imaga, N.O.A., Gbenle, G.O., Okochi, V.I., Adenekan, S.O., Edeoghon, S.O., Kehinde, M. O., Bamiro, S.B., Ajiboye, A. and Obinna, A. 2010. Antisickling and toxicological profiles of leaf and stem of Parquetina nigrescens L. Journal of Medicinal Plants Research, 4(8):639-643.

IwU, M.M. 1994. Handbook of African Medicinal Plants. CRC Press, pp. 38.

Jamroz, D., Wiliczkiewicz, A., Wertelecki, T., Orda, J. and Skorupinska, J. 2005. Use of active substances immune response in broilers. Journal of Chinese Society Animal Science 36:135-146.

Janssen, W.M.M.A. 1989. European tables of energy values for poultry feed stuffs. 3rd ed. Beekbergen Netherlands. 
(Spelderhort Centre for Poultry Research and Information Services) pp: 84.

\section{Kagya-Agyemang, J.K., Takyi-} Boampong, G., Adjei, M. and KarikariBonsu, F.R. 2007. A note on the effect of Gliricidia sepium leaf meal on the growth performance and carcass characteristics of broiler chickens. Journal of Animal and Feed Science, 16,104-108.

Liaqat, S., Mahmood, S., Ahmad, S., Kamran, Z. and Koutoulis, K.C. 2016. Replacement of canola meal with Moringa oleifera leaf powder affects performance and immune response in broilers. Journal of Applied Poultry Research, 25, 352-358.

Lillehoj, H.S., Kim, D.., Bravo, D.M. and Lee, S.H. 2011. Effects of dietary plantderived phytonutrients. Microbiology and Infectious Diseases 31(5):389-402.

Manjaniq, A., Wihandoyo, and Dono, N.D. 2017. The effect of dietary violet Roselle flower and Moringa leaf meal supplementation on blood profile of broiler chickens. Proceedings of the $7^{\text {th }}$ International Seminar on Tropical Animal Production. Contribution of livestock Production on Food Sovereignity in Tropical Countries. 12-14 September 2017, Yogyakarta Indonesia.

\section{Mashayekhi, H., Mazhari, M. and}

Esmaeilipour, O. 2018. Eucalyptus leaf powder, antibiotic and probiotic addition to broiler diets: effects on growth performance, immune response, blood components and carcass traits. Journal of Animal Science, 12, 2049-2055.
Merlin, N.D., Simeon, P.C.F., Guy, S.S.N., Charles, F., Donald, S.T., Fabrice, $K$ and Donatien, G. 2017. Antibacterial activities and toxicological study of the aqueous extract from leaves of Alchornea cordifolia (Euphorbiaceae). BMC Complementary and Alternative Medicine 17: 349.

Mmereole, F.U.C. 2010. Effects of Lemmon grass (Cymbopogon citratus) leaf meal supplement on growth performance of broiler chicks. International Journal of Poultry Science 9(12):1107-1111.

Murugesan, G.R., Syed, B., haldar, S. and Pender, C. 2005. Phytogenics feed additives as an alternative nutrient digestibility and caecal microflora composition. Animal feed science of plant origin in chicken diets based on maize and locally grown cereals. British Poultry Science 46:485-493.

Nodu, M.B., Okpeku, M. and Abezi, A.E. 2014. Haematological characteristics of young rabbits fed a mixture of Alchornea cordifolia/pawpaw leaf meal. Journal of Agriculture and Veterinary Science. Volume 7, Issue 1, Ver. IV, pp 92-96.

Oliver, B. 1986. Medicinal plants in tropical West Africa. Cambridge University Press. Great Britain. Pp 357.

\section{Oloruntola, O.D., Ayodele, S.O., Agbede,} J.O. and Oloruntola, D.A. 2016. Effect of feeding broiler chickens with diets containing Alchornea cordifolia leaf meal and enzyme supplementation. Archivos de Zootecnia 65:489-498. 
Omale, J. and Ugwu, C.E. 2010. Comparative study on the protein and mineral composition of some selected Nigerian vegetables. African Journal of Food Science 5(1):22-25.

Onyimonyi, A.E. and Ernest, O. 2009. An assessment of pawpaw leaf meal as protein ingredient for finishing broiler. International Journal of Poultry Science, 8, 995-998.

Osuntokun, O.T. and Olajubu, F.A. 2014. Comparative study of phytochemical and proximate analysis of seven Nigerian medicinal plants. Applied Science Research Journal 2(1):10-26.

Oyekunle, I.P., Nwogu, U.S., Orababa, O.Q., Nsude, C., Ikpa, J. O. and Azuka, D. C. 2019. Phytochemical, antimicrobial and proximate composition of Nicotiana tabacum leaves extract. International Journal of Innovative Science and Research Technology, 4(5):405-410.

Pandey, A. and Shweta, M. 2011. Antifungal properties of Psidium guajava leaves and fruits against various pathogens. Pharmaceutical Biomedical Science Journal, 13:16.

Pearson J. 1976. Determination of phytic acid and phosphorus content of biological materials. Cambridge University Press, London.

Philip, C.N.A., Elijah, I.O. and Amos, E.K. 2014. Performance evaluation of New Zealand white rabbits fed Alchornea cordifolia leaf meal as replacement for soya bean meal. American Journal of Agriculture and Forestry. 2(2):51-54.

Prakoso, Y.A., Puspitasari, R.C.S., Aliviameita, A., Salasia, S.I.O., Kurniasih, Ikram A.F.D., Walangi, B., Utama, K.P., Al Huda, M.F. and Su'udiyah, N.A. 2018. The role of Sauropus androgynus (L) Merr. leaf powder in the broiler chickens fed a diet naturally contaminated with aflatoxin. Journal of Toxicology, Volume 2018, Article ID 2069073, 18 pages https://doi.org/10.1155/2018/2069073.

Rama, R. S.V., Raju, M.V.L.N., Prakash, B., Rajkumar, U. and Reddy, E. P. K. 2019. Effect of supplementing moringa (Moringa oleifera) leaf meal and pomegranate (Punica granactum) peel meal on performance, carcass attributes, immune and antioxidant responses in broiler chickens. Animal Production Science 56: 288-294.

Reinik, M., Tamme, T., Roasto, M., Juhkam, K., Tenno, T. and Kiis, A. 2007. Polycyclic Aromatic Hydrocarbons (PAHs) I Meat Products and Estimated PAH Intake by Children and the General Population in Estonia. Food additives \& Contaminants, 24, 429-437.

Ross, I.A. 1999. Medicinal plants of the World. Chemical constituents, traditional and modern medical uses. Human Press, New Jersey.

Sambo, S.H., Olatunde, A. and Johnson, O.T. 2015. Nutritional and anti-nutritional composition of Lantana camara leaf. 
Journal of Investigational Biochemistry $4(2): 58-60$.

Sanjeeb, K., Gaurav, K., Loganathan, K and Kokati, V.B.R. 2012. A review on medicinal properties of Lantana camara Linn. Research J. Pharm. and Tech. 5(6):711-715.

SPSS 2015. Statistical Package for Social Sciences. SPSS 23 Statistics Premium for Windows. IBM Corporation computer software package version 23,32 and 64 bit, Jordan.

Sumaira, A., Zahida, T., Zeshan, S., Nisar, A. and Mushtaq, H.L. 2015. The Effects of oil spreparation of Ginger and its effects on hyperlipidemia. Pakistan Journal of Nutrition 12: 1134-1137.

Verma, R.K. and Verma, S.K. 2006. Phytochemical and Termicidal study of Lantana camara var. aculeate leaves. Fitoterapia. 77:466-468. 